\title{
A MINI-OVERVIEW OF VITAMIN D
}

\author{
By \\ AHMAD H. F. EL-TAWDY ${ }^{1}$, MOSTAFA SHABAN AHMED HEMDAN ${ }^{1}$, \\ WEJDAN ESSAM AHMED ISA ${ }^{2}$ and TOSSON A. MORSY ${ }^{3}$ \\ Military Medical Academy, Cairo $11291^{1}$, and Senior Resident, Bahrain Defence \\ Force Hospital ${ }^{2}$, and Faculty of Medicine, Ain Shams University, Cairo $11566^{3}$ \\ Abstract
}

Generally speaking, vitamins are essential for man and animal. Vitamin D is essential for good overall health and strong and healthy bones. It's an important factor in making one sure of his muscles, heart, lungs and brain...etc. Vitamin D and calcium deficiencies are common worldwide, causing nutritional rickets and osteomalacia, which have a major impact on health, growth, and development of infants, children, and adolescents; consequences can be lethal or can last into adulthood. This mini-review gives an overview of vitamin D.

Keywords: Vitamin D, Sources, Deficiency, Repletion, Calcium, Insect allergy, Type 2 diabetes mellitus.

\section{Introduction}

Generally, the vitamins are chemically unrelated families of organic compounds; essential in small amounts for normal metabolism. Because vitamins (with exception of vitamin D) cannot be synthesized by humans, they need to be ingested in the diet to prevent disorders of metabolism. Vitamins are divided into water-soluble and fat-soluble (Tab. 1). Vitamin D is a fat-soluble one.

\section{Review and Discussion}

Deficiency of vitamin D (commonly referred to as "rickets" in children) is of unique historical value. Rickets was first described in the mid-1600s by Whistler and Glisson (Fraser and Scriver, 1979), but for decades thereafter, no progress was made in identifying the cause. Sir Edward Mellanby described the deficiency of a fat-soluble nutrient as the cause for rickets (Mellanby, 1918). Then thereafter, Goldblatt and Soames (1923) demonstrated that skin exposed to sunlight or ultraviolet light produced a substance with similar properties to this fatsoluble nutrient. This ultimately led to the discovery of the chemical structure of vitamin D (Windaus et al, 1936). Vitamin D and its metabolites have a significant clinical role because of their interrelationship with calcium homeostasis and bone metabolism. Rickets due to vitamin D deficiency is now rare except in populations with unusually low sun exposure and lack of vitamin $\mathrm{D}$ in fortified foods (Gordon et al, 2004). Subclinical vitamin D deficiency, as measured by low levels of 25OHD, has been described among adolescents (Das et al, 2006) and the elderly, and may contribute to development of osteoporosis and an increased risk of fractures and falls in elderly (Lips et al, 2006). Besides, its role in calcium and bone homeostasis, vitamin D potentially regulates many other cellular functions (Holick, 2006).

Chemistry: Vitamin D, or calciferol, is a generic term and refers to a group of lipid soluble compounds with a four-ringed cholesterol backbone.

Sources: Two methods have been developed for direct evaluation of the Vitamin D synthetic capacity of sunlight (and artificial UV sources). The first one uses an in vitro model of Vitamin $\mathrm{D}(3)$ synthesis (ethanol solution of 7-dehydrocholesterol, 7-DHC), and concentration of previtamin $\mathrm{D}(3)$ accumulated during an UV exposure is determined using specially designed spectrophotometric analysis. The second method utilizes photoisomerization of provitamin $\mathrm{D}$ in nematic liquid crystalline (LC) matrix, and visual estimation of accumulated previtamin $\mathrm{D}$ becomes possible due to special design of a LC cell (Terenetskaya, 2004).

Intestinal absorption is the other major source of vitamin D. As part of the diet, vitamin D is found in fortified milk, fatty fish, and cod-liver oil and, to a lesser extent, 
eggs. In the United States, milk fortified with vitamin D2 (ergocalciferol, a plant steroid) or vitamin D3 (cholecalciferol) is the principal source of dietary vitamin D. In other parts of the world, cereals and bread products were often fortified with vitamin D (Mansbach et al, 2009).

Absorption and metabolism: Dietary vitamin D is incorporated into micelles, absorbed by enterocytes, and then packaged into chylomicrons. Disorders associated with fat malabsorption, such as celiac disease, Crohn disease, pancreatic insufficiency, cystic fibrosis, and cholestatic liver disease, are associated with low serum 25-hydroxyvitamin D levels. Chylomicrons are transported to the liver via the portal circulation where vitamin D undergoes a hydroxylation process by 25-hydroxylase to form 25-hydroxyvitamin D (25OHD). Further hydroxylation of 25-hydroxyvitamin D to 1,25-dihydroxyvitamin D $(1,25 \mathrm{OHD})$ occurs in the mitochondria of the proximal tubules of the kidney. $1,25 \mathrm{OHD}$ is the physiologically active form of vitamin D, with more than 25 metabolites identified, each with different biologic activities (Henry and Norman, 1974).

The synthesis of vitamin D and its metabolism to $1,25 \mathrm{OHD}$ is closely coupled to calcium homeostasis, and is modulated by parathyroid hormone, serum calcium, and phosphorus levels (Holick, 1989). When hypocalcemia occurs, serum PTH concentration increases and enhances tubular reabsorption of calcium, as well as the activity of alpha-1hydroxylase in the kidney (Holick et al, 1995). This results in increased $1,25 \mathrm{OHD}$ production and, in turn, intestinal calcium absorption (Holick, 1994). PTH also stimulates bone osteoclast activity to mobilize bone calcium stores, thereby increasing serum calcium (Holick, 1996). Estrogen, placental growth hormone, and prolactin may also regulate vitamin D metabolism, playing a role during pregnancy to meet increased calcium demands (Kovacs and Kronenberg, 1997).

Metabolism of vitamin D: Vitamin $\mathrm{D}_{3}$ is made in the skin from 7-dehydrocholesterol under the influence of UV light. Vitamin $\mathrm{D}_{2}$ (ergocalciferol) is derived from the plant sterol ergosterol. Vitamin D is metabolized first to 25 hydroxyvitamin D (25OHD), then to the hormonal form 1,25-dihydroxyvita$\min \mathrm{D}\left(1,25(\mathrm{OH})_{2} \mathrm{D}\right)$. CYP2R1 is the most important 25-hydro-xylase; CYP27B1 is the key 1-hydroxylase. Both 25OHD and 1,25 $(\mathrm{OH})_{2} \mathrm{D}$ are catabolized by CYP24A1. 1,25 $(\mathrm{OH})_{2} \mathrm{D}$ is the ligand for the vitamin $\mathrm{D}$ receptor (VDR), a transcription factor, binding to sites in the DNA called vitamin D response elements (VDREs). There are thousands of these binding sites regulating hundreds of genes in a cell-specific fashion. VDR-regulated transcription is dependent on comodulators, the profile of which is also cell specific. Analogs of $1,25(\mathrm{OH})_{2} \mathrm{D}$ are being developed to target specific diseases with minimal side effects (Bikle, 2014).

Skeletal development and regulation of bone formation and resorption: Skeleton is a highly dynamic organ that constantly undergoes changes and regeneration. It consists of specialized bone cells, mineralized and unmineralized connective tissue matrix, and spaces that include the bone marrow cavity, vascular canals, canaliculi, and lacunae containing osteocytes. Bone also contains water, which represents at least $25 \%$ of its wet weight and provides much of its unique strength and resilience. Skeleton has structural and metabolic functions: Its structural function is critical for locomotion, respiration, and protection of internal organs. The structural connection between the skeleton and the hematopoietic system is particularly intimate; these two systems share both cells and local regulatory factors. Its metabolic function is largely as a storehouse for calcium, phosphorus, and carbonate and contributes to buffering changes in hydrogen ion concentration (Goltzman et al, 2015).

Deficiency and resistance: Vitamin D deficiency or resistance is caused by one of four mechanisms (Sahota, 2014): 1-Impaired availability of vitamin $\mathrm{D}$, secondary to inad- 
equate dietary vitamin $\mathrm{D}$, fat malabsorptive disorders, and/or lack of photoisomerization. 2- Impaired hydroxylation by liver to produce 25-hydroxyvitamin D. 3- Impaired hydroxylation by kidneys to produce 1,25-dihydroxyvitamin D. \& 4- End organ insensitivity to vitamin $\mathrm{D}$ metabolites; hereditary vitamin D resistant rickets (Misra et al, 2008).

Lack of vitamin D activity leads to reduced intestinal absorption of calcium and phosphorus. Early in vitamin D deficiency, hypophosphatemia is more marked than hypocalcemia. With persistent vitamin D deficiency, hypocalcemia occurs and causes the secondary hyperparathy-roidism that leads to phosphaturia, demineralization of bones and, when prolonged, to osteomalacia in adults and rickets in children. Muirhead et al. (1982) treated 23 patients with end-stage renal failure on maintenance haemodialysis with 1,25-dihydroxy vitamin D3 or 24-25dihydroxy vitamin D3 for 3-32 months (total 232 patient months). They confirmed that 1,25-dihydroxy vitamin D3 was effective in controlling clinical, biochemical and histological features of renal osteodystrophy while 24,25-dihydroxy vitamin D3 did not have a useful therapeutic effect in the dose used. Hazzazi et al. (2013) studied the causes and clinical presentations of osteomalacia/rickets in adolescents, at the King Abdulaziz Medical City, Riyadh. They reported that osteomalacia was a significant health burden. They added that bone pain was the commonest symptom at diagnosis. Because of the high risk of osteomalacia associated with the use of anticonvulsants and steroids, it was advised that all patients on these drugs should be routinely screened for secondary osteomalacia. Wouters et al. (2015) in Europe stated that Rickets was a rare disease in developed countries, which affects growing bone. They reported two cases presenting with poor growth, severe pain, and respiratory problems secondary to calcipenic rickets. Munns et al. (2016) stated that vitamin $\mathrm{D}$ and calcium deficiencies are common worldwide, causing nutritional rickets and osteomalacia, which have a major impact on health, growth, and development of infants, children, and adolescents; the consequences can be lethal or can last into adulthood. They concluded that rickets, osteomalacia, and vitamin $\mathrm{D}$ and calcium deficiencies must be preventable global public health problems in the infants, children, and ado-lescents, and that implementation of international rickets prevention programs, including supplementation and food fortification, is urgently required.

Glucocorticoids, when used chronically in the high doses, inhibit intestinal vitamin Ddependent calcium absorption and therefore can cause osteomalacia. Guerreiro et al. (2007) reported that parathyroid hormone (PTH) and PTH-related protein (PTHrP) are factors sharing amino acid sequence homology and act via a common receptor. In tetrapods, PTH is the main endocrine factor acting in bone and kidney to regulate calcium and phosphate. PTHrP is an essential paracrine developmental factor present in many tissues and is involved in the regulation of ossification, mammary gland development, muscle relaxation, and other functions. Fish apparently lack an equivalent of the parathyroid gland and were long thought to be devoid of PTH. The existence of PTH-like peptides and their receptors in fish was firmed. Two forms of PTH, two of PTHrP, and a protein with intermediate characteristics designated PTH-L are encoded by separate genes in teleost fish. Three receptors encoded by separate genes in fish mediate PTH/PTHrP actions, whereas only two receptors have so far been found in terrestrial vertebrates. PTHrP has been more intensively studied than PTH, from lampreys to advanced teleost. It is expressed in many tissues with high concentration in fish blood. Administration of this peptide alters calcium metabolism and has marked effects on associated gene expression and enzyme activity in vivo and in vitro. This review provides a comprehensive overview of the physiological roles, distribution, and molecular rela- 
tionships of the piscine PTH-like peptides. Gröber and Kisters (2012) reported that several drugs interfere with the vitamin D and bone metabolism. Drugs activate the pregnane $\mathrm{X}$ receptor disrupted vitamin $\mathrm{D}$ metabolism and vitamin D function. Also, medication oriented supplementation of the vitamin $\mathrm{D}$ ameliorated the pharmacologic action of some drugs, such as bisphosphonates, cytostatics and statins

Vitamin D stores decline with age, especially in the winter. Controlled trials have demonstrated that vitamin D and calcium supplementation can reduce the risk of falls and fractures in the elderly. Boucher (2912) reported that Loss of mobility or residential care restricts solar exposure. Reduced appetite and financial problems often add to these problems. Thus, hypovitaminosis D is common world-wide, but is more common and more severe in older people. Non-classical effects of vitamin $\mathrm{D}$, depending on serum circulating 25-hydroxyvitamin D concentrations, are present in most non-bony tissues; disorders associated with hypovitaminosis D include increased risks of sepsis [bacterial, mycobacterial and viral], cardiovascular and metabolic disorders [e.g. hyperlipidemia, type 2 diabetes mellitus, acute vascular events, dementia, stroke and heart failure]. Many cancer risks are associated with vitamin D inadequacy, though causality is accepted only for colo-rectal cancer. Maintenance of repletion in healthy older people requires intakes of $\geq 800 \mathrm{IU} /$ day $[20 \mu \mathrm{g}]$, as advised by the Institute of Medicine [IOM], but achieving such intakes usually requires supplementation. Excessive intakes are dangerous, especially in undiagnosed primary hyperparathyroidism or sarcoidosis, but the IOM finds doses <4000 IU/day are safe. Many experts suggest that $\geq 1000-2000$ IU $(25-50 \mu \mathrm{g})$ of vitamin D daily is necessary for older people, especially when independence was lost, or hypovitaminosis D could add to the clinical problem(s). Much higher doses than these are needed for treatment of established deficiency or insufficiency.
Calcium and vitamin D in osteoporosis: Sunyecz (2008) stated that osteoporosis poses a significant public health issue, causing significant morbidity and mortality. Calcium and vitamin D utilization in the optimization of bone health is often overlooked by patients and health care providers. In addition, the optimal standard of care for osteoporosis should encompass adequate calcium and vitamin D intake. Compliance to calcium and vitamin $\mathrm{D}$ therapy is paramount for effective prevention of osteoporotic fractures. A recently released algorithm (FRAX) estimating absolute fracture risk allows the health care provider to decide when pharmacologic therapy is warranted in addition to calcium and vitamin $\mathrm{D}$. When pharmacologic therapy is advised, continued use of calcium and vitamin $\mathrm{D}$ is recommended for optimal fracture risk reduction.

Benefits of vitamin D repletion: Overt vitamin D deficiency, characterized by the hypocalcemia and/or hypophosphatemia and rickets and osteomalacia in children and osteomalacia in adults, is now uncommon in most developed countries. However, the subclinical vitamin D deficiency occurs even in developed countries associated with osteoporosis, increased risk of falls, and possibly fractures as well as aging (MacLaughlin and Holick, 1985). Vitamin D stores decline with age, especially in the winter (Tsai et al, 1987). In temperate areas such as Boston and Edmonton, for example, cutaneous production of vitamin D virtually ceases in winter (Webb et al, 1988). Thus, identification and treatment of vitamin D deficiency is important for musculoskeletal health and possibly even extraskeletal health, including the immune and cardiovascular systems. Generally, better vitamin $\mathrm{D}$ repletion may contribute to reducing chronic inflammatory problems such as periodontitis (Jabbar et al, 2011) and atheromatous disease, and might reduce acute vascular events due to arterial plaque disruption, inflammation being a major factor in atheromatous disease progression (Zhou et al, 1999). Tuberculosis infec- 
tions were treated with sunshine and/or vitamin D before the anti-tuberculous drugs emerged. Sputum conversion rates fall with supplementation, but only in specific VDR genotypes (Martineau et al, 2011). Vitamin D status relates inversely to the circulating MMP9, a marker of atheromatous damage, which failed after supplementation (Timms et al, 2002). MMP9 formation in tuberculous lesions was suppressed by vitamin D (Coussens et al, 2009).

Wound healing, often slow in older ages, was enhanced experimentally by vitamin D (Tian et al, 1995). Hypovitaminosis D was associated with increased pressure sore risks in community dwellers in their 70 s to 90 s but not as an independent determinant since hypovitaminosis D was determined by existing co-morbidities (Kalav et al, 2011).

Clearly, adequate RCTs of supplementation are required to see whether causality can be demonstrated. Low baseline vitamin D status predicted reduced healing in the year after surgery for periodontitis, a common problem in older people, and giving vitamin D to subjects with severe periodontal problems improved post-operative bone defect resolution, supporting suggestions that the hypovitaminosis D may worsen periodontitis (Bashutski et al, 2011). Organ rejection risks after transplantation are reduced by vitamin $\mathrm{D}$ supplementation (Bitetto et al, 2010). If causality can be demonstrated for any or all of these suggestions by adequate RCTS of vitamin D supplementation, then provision of adequate vitamin $\mathrm{D}$ was used in these situations management (Holick, 2011)

Several studies have shown suboptimal serum levels of 25OHD and vitamin D intake in children in the United States and other countries (Cole et al, 2010).

Excess: In the 1940s and 1950s, a number of children developed hypercalcemia, sometimes associated with brain injury, thought to be a result of high concentrations of vitamin D in fortified milk products. Chronic intoxication may cause bone demineralization and pain. Vitamin D intoxication may occur in fad dieters who consume "megadoses" of supplements or in patients who take vitamin D replacement therapy for malabsorption, renal osteodystrophy, osteoporosis, or psoriasis (Gartner et al, 2005). Vitamin D intoxication was documented in adults taking more than 60,000 international units per day (Morgan and Weinsier, 1998). Keshtkar et al. (2015a) in Iran reported that few data on the efficacy of incremental doses of vitamin D from fortified foods among adolescents. They added that in developing countries an optimal model to fight vitamin $\mathrm{D}$ deficiency needs further research on bone health outcomes and the safety of vitamin Dfortified products. The modified version of this protocol could be applied in different parts of the country to assess the efficacy of a vitamin-D product. Symptoms of acute intoxication are due to hypercalcemia and include the confusion, polyuria, polydipsia, anorexia, vomiting, and muscle weakness. Keshtkar et al. (2015b) added that there must be a protocol, to be implemented with small modifications, can help policymakers in different parts of the world, particularly developing countries, and gather accurate information on the different aspects of bone health at the national level.

Requirements: The Institute of Medicine (IOM, 2010) released a report on dietary intake requirements for calcium and vitamin D. The dietary reference intakes were based upon the beneficial effects of calcium and vitamin $\mathrm{D}$ on skeletal health. The evidence supporting a benefit of vitamin D on extra skeletal outcomes was inconsistent, inconclusive as to causality, and insufficient, and therefore could not serve as a basis for dietary reference intake development (Ross et $a l, 2011)$. The intake at which the dose of vitamin D becomes toxic is not clear. The Institute of Medicine has defined the "tolerable upper intake level" (UL) for the vitamin $\mathrm{D}$ as 100micro-grams (4000 international units) daily for healthy adults and children 9 to 18 years. This is also the UL for pregnant and lactating women. The UL for infants 
and children up to nine years old is lower (Tab. 2). Indications for high dose vitamin D supplementation and the UL for vitamin D supplementation are discussed in more detail separately

Estimates of vitamin D requirements vary, depend in part upon sun exposure and the standards used to define a deficient state. The Institute of Medicine (IOM, 2010) committee assumed minimal sun exposure when establishing the dietary reference intakes for vitamin $\mathrm{D}$. The committee also concluded that a serum 25-hydroxyvitamin D concentration of $20 \mathrm{ng} / \mathrm{mL}(50 \mathrm{nmol} / \mathrm{L})$ was sufficient for most individuals.

The Recommended Dietary Allowance (RDA) of vitamin D for children 1 to 18 years and adults through age 70 years is 600 international units $(15 \mathrm{mcg})$ with the RDA increasing to 800 international units (20mcg) after age 71 (Tab. 2). For pregnant and lactating mothers, intake of 600 international units $(15 \mathrm{mcg})$ is recommended. However, some studies suggest that higher intakes may be necessary to maintain normal levels of 25OHD during the pregnancy and lactation (Hollis and Wagner, 2004a).

Vitamin D supplementation should be given to infants who are exclusively breast fed as vitamin D content of human milk is low. The Lawson Wilkins Pediatric Endocrine Society recommends supplementation with 400international units (units) daily of vitamin D beginning within days of birth for infants who are exclusively breast-fed. Most infant formulas contain at least 400 units/L of vitamin $\mathrm{D}$, so formula-fed infants will also require supplementation to meet this goal unless they consume at least $1000 \mathrm{~mL}$ daily of formula. Vitamin D intake of at least 400units/day also recommended for children who do not consume at least one liter of vitamin D fortified milk daily (Hollis and Wagner, 2004b). Wagner et al. (2008) reported that rickets in infants attributable to inadequate vitamin D intake and decreased exposure to sunlight continues in the United States. There are also concerns for vitamin
D deficiency in older children and adolescents. Because there are limited natural dietary sources of vitamin D and adequate sunshine exposure for the cutaneous synthesis of vitamin D is not easily determined for a given individual and may increase the risk of skin cancer, the recommendations to ensure adequate vitamin D status have been revised to include all infants, including those who are exclusively breastfed and older children and adolescents. It is now recommended that all infants and children, including adolescents, have a minimum daily intake of 400 IU of vitamin D must be after birth. The current recommendation replaces the previous recommendation of a minimum daily intake of $200 \mathrm{IU} /$ day of vitamin D supplementation beginning in the first 2 months after birth and continuing through adolescence. They revised guidelines for vitamin $\mathrm{D}$ intake for healthy infants, children, and adolescents are based on evidence from new clinical trials and the historical precedence of safely giving $400 \mathrm{IU}$ of vitamin D/day in the pediatric and adolescent population. New evidence supports a potential role for vitamin $\mathrm{D}$ in maintaining innate immunity and preventing diseases such as diabetes and cancer.

Casual exposure to sunlight gives amounts of vitamin $\mathrm{D}$ that are adequate to prevent rickets in many people, but is influenced by geographic location, season, use of sun block lotion, and skin pigmentation. As an example, a Caucasian infant's vitamin D requirements are met by exposure to sunlight for 30 minutes per week, clothed only in a diaper, or two hours per week fully clothed without hat (WHO, 2002). African-American individuals require approximately threefold longer periods of sunlight exposure because of the protective pigmentation in their skin (Clemens et al, 1982). Currently recommended sun exposure for infants is insufficient to maintain vitamin $\mathrm{D}$ levels in the recommended range for dark-skinned infants and children, particularly at high latitudes and during the winter months. Brok et al. (2011) stated that The Danish Board of Hea- 
lth recommended that: pregnant women are treated with a daily dose of vitamin D daily (10 micrograms); the emigrants with colored skin have their vitamin D level assessed during pregnancy; all children receive a daily dose of vitamin D (10 micrograms) until two years old. Despite of these recommendations two cases of the severe nutritional rickets among the emigrants children were discovered upon hospital admission. The symptoms were heterogeneous: delayed walking skills and convulsions. So, nutritional rickets is a tricky diagnosis, but is preventable.

Vitamin D requirements also may depend on disease states and concomitant medications. As an example, patients undergoing long-term treatment with steroids may benefit from higher levels of supplementation of vitamin D and calcium (De Sévaux et al, 2002). The best laboratory indicator of vitamin $\mathrm{D}$ adequacy is the serum 25-hydroxyvitamin D (25OHD) concentration. The lower limit of normal for 25OHD levels varies depending on the geographic location and sunlight exposure of the reference population (range $8-15 \mathrm{ng} / \mathrm{mL}$ ). But, there was no consensus on the optimal 25OHD concentration for skeletal or extraskeletal health. The IOM (2010) suggested that a level of 20ng/ $\mathrm{mL}(50 \mathrm{nmol} / \mathrm{L})$ is adequate. Vieth (1999) reported that for adults, the $5 \mu \mathrm{g}$ (200 IU) vitamin $\mathrm{D}$ recommended dietary allowance may prevent osteomalacia in absence of sunlight, but more needed to help prevent osteoporosis and secondary hyperparathyroidism. Other benefits of vitamin D supplementation were epidemiological implicated: Prevention of some cancers, osteoarthritis progression, multiple sclerosis, and hypertension. Total-body sun exposure easily provided equivalent of $250 \mu \mathrm{g}$ (10000 IU) vitamin D/d, suggesting a physiologic limit. Sailors in US submarines were deprived of environmentally acquired vitamin $\mathrm{D}$ equivalent to $20-50 \mu \mathrm{g}(800-2000 \mathrm{IU}) / \mathrm{d}$. The assembled data from many vitamin D supplementation revealed a curve for vitamin $\mathrm{D}$ dose vs. serum 25-hydroxy-vitamin D 25(OH)D respo- nse that was surprisingly flat up to $250 \mu \mathrm{g}$ (10000 IU) vitamin D/d. He added that to ensure serum $25(\mathrm{OH}) \mathrm{D}$ concentrations exceeded $100 \mathrm{nmol} / \mathrm{L}$, a total vitamin D supply of $100 \mu \mathrm{g}(4000 \mathrm{IU}) / \mathrm{d}$ was required. Except in those with conditions causing hypersensitivity, without evidence of adverse effects with serum $25(\mathrm{OH}) \mathrm{D}$ concentrations < 140$\mathrm{nmol} / \mathrm{L}$ that require a total vitamin $\mathrm{D}$ supply of $250 \mu \mathrm{g}(10000 \mathrm{IU}) / \mathrm{d}$ to attain. Published cases of vitamin $\mathrm{D}$ toxicity with hypercalcemia, for which $25(\mathrm{OH}) \mathrm{D}$ concentration and vitamin $\mathrm{D}$ dose were known, all involve intake of $\geq 1000 \mu \mathrm{g}(40000 \mathrm{IU}) / \mathrm{d}$. Because vitamin D is potentially toxic, intake of $>25 \mu \mathrm{g}$ (1000 IU)/d was avoided even though the weight of evidence showed that the currently accepted, no observed adverse effect limit of $50 \mu \mathrm{g}(2000 \mathrm{IU}) / \mathrm{d}$ was too low by at least 5fold. The serum parathyroid hormone (PTH) level typically is inversely related to $25-\mathrm{OH}$ vitamin $\mathrm{D}$ levels in adults, and might be a useful secondary indicator of vitamin D insufficiency, which is weak for children.

Other Vitamin D input in some diseases:

Lung: better vitamin D status was associated with better lung function, independent of other factors including allergic status and in chronic pulmonary disease (CPD) though not in all cohorts. But, there could be an element of reverse causation in these associations since reduced exercise capacity may well reduce outdoor activity (Topannen et al, 2011).

Respiratory infection risk was high in renal failure but reduced in those on calcitriol (Tsujimoto et al, 2011). The new onset diabetes, hypertension and early cardiovascular death in patients on dialysis are major problems but replacement of vitamin D activity can reduce the risk of, or even correct glucose intolerance, reduce blood pressure and greatly reduce CVD mortality. However, this risk could increase if unduly high replacement doses were used, narrowing the therapeutically acceptable range of dosage of activated vitamin D (Tillis et al, 2011).

Vision: Vitamin D is postulated to protect 
eyes from some common changes of ageing, including inflammation (Lee et al, 2012).

Chronic renal: Renal function falls with age and renal failure in older age is increasingly managed actively. Since renal activation of vitamin $\mathrm{D}$ is lost with extensive renal damage, renal osteodystrophy was a common and potentially severe bone disease for which activated vitamin D or its analogues are usually given as prophylaxis, together with measures for controlling serum calcium and phosphate concentrations. Respiratory infection risk was high in renal failure but reduced in those on calcitriol (Tsujimoto $e t$ $a l, 2011)$. New onset diabetes, hypertension and early cardiovascular death in patients on dialysis are major problems but replacement of vitamin D activity can reduce the risk of, or even correct glucose intolerance, reduce blood pressure and greatly reduce the CVD mortality (Tillis et al, 2011).

Ageing is associated with reduced peripheral arterial endothelium-dependent dilatation, probably due to increases in oxidative stress and reductions in locally synthesized nitric oxide. Whilst vascular endothelial function is adversely affected by lack of exercise, obesity, the menopause and other factors, and reduced in hypovitaminosis D (Seals et al, 2011) and was improved by supplementation (Ertek et al, 2012). Compliance (elasticity) of blood vessel walls falls with age and is associated with increases in blood pressure, as also seen with age.

Cancer: many cancers were more common in vitamin D deficiency and there is much convincing epidemiological and especially ecological evidence (Grant, 2012). But, only in colo-rectal cancer was available evidence accepted as demonstrating causality by bodies such as the International Agency for Research against Cancer (IARC, 2008).

Insect allergy: Keating et al. (2014) reported Vitamin D deficiency enhanced house dust mites induced influx of lymphocytes into BAL, ameliorated HDM-induced increased, and protected against the HDM-induced increase in baseline airway resistance. They added that Vitamin D decreased inflammatory cytokine profiles in TH9 memory cells \& CD4 (+) cells stimulated with HDM allergen, and was additive with dexamethasone in decreasing inflammatory cytokine production from T-cell subsets implicated in asthma. Vitamin D supplementation ameliorated atopic dermatitis severity as safe and tolerable therapy (Kim and Bae, 2016) as well as insect bites (Morsy, 2012) and Skeeter Syndrome (Abdel-Motagaly et al, 2017).

Information for patients: One must offer two types of patient education materials, "the basics" and "beyond the basics." The basics patient education pieces are written in plain language, at the $5^{\text {th }}$ to $6^{\text {th }}$ grade reading level, and they answer the four or five key questions a patient might have about a given condition. These articles are best for patients who want a general overview and who prefer short, easy-to-read materials. Beyond the Basics patient education pieces are longer, more sophisticated, and more detailed. These articles are written at the $10^{\text {th }}$ to $12^{\text {th }}$ grade reading level and are best for patients who want in-depth information and are comfortable with some medical jargon.

Here are the patient education articles that are relevant to this topic. One encourages the patient to print or e-mail these topics to your patients. (You can also locate patient education articles on a variety of subjects by searching on "patient info" and the keyword(s) of interest.).

Type 2 diabetes mellitus: Though there are strong associations of reductions in vitamin D status, but assessed, with increased risks of type 2 diabetes in many reported studies and in a few prospective studies were reported, very few randomized controlled trials were carried out to see whether correction of insufficiency can prevent T2DM diabetes. This is ongoing and will be published in due time by El-Tawdy et al. (In press)

\section{Recommendations}

Very few foods contain vitamin D; fatty fish and eggs are the exceptions. Dermal synthesis and foods fortified with vitamin D 
are the major sources of the vitamin. Vitamin D3 (cholecalciferol) is synthesized nonenzymatically in skin from 7-dehydrocholesterol during exposure to the ultraviolet rays in sunlight. Cholecalciferol from the skin or diet must be 25-hydroxylated in the liver, then 1-hydroxylated in the kidneys to the active form, 1,25-dihydroxycholecalciferol (calcitriol) Vitamin D deficiency can be caused by unusually low sun exposure combined with lack of vitamin D fortified foods or malabsorption. Alternatively, impaired hydroxylation of vitamin D in liver or kidney can prevent metabolism into the physiologically active form. Rarely, genetic defects may cause the end organs to be unresponsive to vitamin $\mathrm{D}$, as in hereditary vitamin $\mathrm{D}$ resistant rickets (HVDRR). The Recommended Dietary Allowance for vitamin D is 600 international units (units) for adults through age 70 years and for children 1 to 18 years of age. For adults 71 years and older, 800 units (20 micrograms) daily is recommended for the prevention and treatment of osteoporosis. The excessive doses of vitamin D supplements in adults can result in intoxication. Acute intoxication symptoms are due to hypercalcemia; as confusion, polyuria, polydipsia, anorexia, vomiting, and muscle weakness. Long-term intoxication can cause bone demineralization, pain, and hypercalcemia in children, can cause brain injury.

The Institute of Medicine defined tolerable upper intake level (UL) for vitamin D as 100micrograms (4000 units) daily for the healthy adults and children 9-18 years. But, the UL for infants and children up to 9 years must be lower.

On the other hand, the supplementation of calcium and/or other nutrients should only be taken if medically indicated. These recommendations provided advice based on the available evidence but do not allow for the possibility that much higher doses may be more beneficial. But, adequate RCT data is not yet available for the potential benefits and risks of doses larger than 4000 IU/day over the long-term.

\begin{tabular}{|c|c|c|}
\hline vitamin & & Deficiency syndrome \\
\hline \multicolumn{3}{|r|}{ Water-soluble vitamins } \\
\hline $\begin{array}{r}\text { Vitamin B1 } \\
\text { (thiamine) }\end{array}$ & $\begin{array}{l}\text { Thiamine pyrophos- } \\
\text { phate }\end{array}$ & $\begin{array}{l}\text { Beriberi - congestive heart failure (wet beriberi), aphonia, peripheral neuropathy, } \\
\text { Wernicke encephalopathy (nystagmus, opthalmoplegia, ataxia), confusion, or coma }\end{array}$ \\
\hline $\begin{array}{l}\text { Vitamin B2 } \\
\text { (riboflavin) }\end{array}$ & $\begin{array}{c}\text { Flavine adenine } \\
\text { dinucleotide }\end{array}$ & $\begin{array}{l}\text { Nonspecific symptoms including edema of mucus membranes, angular stomatitis, } \\
\text { glossitis, and seborrheic dermatitis (eg, nose, scrotum) }\end{array}$ \\
\hline $\begin{array}{l}\text { Niacin } \\
\text { (nicotinic acid) }\end{array}$ & $\begin{array}{l}\text { Nicotinamide ade- } \\
\text { nine dinucleotide }\end{array}$ & $\begin{array}{l}\text { Pellagra - dermatitis on areas exposed to sunlight; diarrhea with vomiting, dysphagia, } \\
\text { mouth inflammation (glossitis, angular stomatitis, cheilitis); headache, dementia, } \\
\text { peripheral neuropathy, loss of memory, psychosis, delirium, catatonia }\end{array}$ \\
\hline $\begin{array}{l}\text { Vitamin B6 } \\
\text { (pyroxidine, pyridoxal) }\end{array}$ & $\begin{array}{l}\text { Transaminase cofac- } \\
\text { tor }\end{array}$ & $\begin{array}{l}\text { Anemia, weakness, insomnia, difficulty walking, nasolabial seborrheic dermatitis, } \\
\text { cheilosis, stomatitis }\end{array}$ \\
\hline $\begin{array}{r}\text { Vitamin B12 } \\
\text { (cobalamin) }\end{array}$ & One carbon transfer & $\begin{array}{l}\text { Megaloblastic anemia (pernicious anemia). Peripheral neuropathy, with impaired } \\
\text { proprioception, and slowed mentation. }\end{array}$ \\
\hline Folate & One carbon transfer & Megaloblastic anemia \\
\hline Biotin & $\begin{array}{l}\text { Pyruvate carboxylase } \\
\text { cofactor }\end{array}$ & $\begin{array}{l}\text { Nonspecific symptoms including altered mental status, myalgia, dysesthesias, anorex- } \\
\text { ia, maculosquamous dermatitis }\end{array}$ \\
\hline Pantothenate & Coenzyme A & $\begin{array}{l}\text { Nonspecific symptoms including paresthesias, dysesthesias ("burning feet"), anemia, } \\
\text { gastrointestinal symptoms }\end{array}$ \\
\hline $\begin{array}{l}\text { Vitamin C } \\
\text { (ascorbate) }\end{array}$ & \begin{tabular}{|c|}
$\begin{array}{c}\text { Antioxidant, collagen } \\
\text { synthesis }\end{array}$ \\
\end{tabular} & $\begin{array}{l}\text { Scurvy - fatigue, petechiae, ecchymoses, bleeding gums, depression, dry skin, im- } \\
\text { paired wound healing }\end{array}$ \\
\hline \multicolumn{3}{|l|}{ Fat-soluble vitamins } \\
\hline $\begin{array}{c}\text { Vitamin A } \\
\text { (retinol, retinal, retinoic acid) }\end{array}$ & $\begin{array}{l}\text { Vision, epithelial } \\
\text { differentiation }\end{array}$ & Night blindness, xerophthalmia, keratomalacia, Bitot's spot, follicular hyperkeratosis \\
\hline $\begin{array}{l}\text { Vitamin D } \\
\text { (cholecalciferol, ergocalcifer- } \\
\text { ol) }\end{array}$ & $\begin{array}{l}\text { Prohormone for } \\
\text { calcium regulation }\end{array}$ & Rickets, osteomalacia, craniotabes, rachitic rosary \\
\hline $\begin{array}{l}\text { Vitamin E } \\
\text { (tocopherols) }\end{array}$ & Antioxidant & Sensory and motor neuropathy, ataxia, retinal degeneration, hemolytic anemia \\
\hline $\begin{array}{l}\text { Vitamin } \mathrm{K} \\
\text { (phylloquinone, menaquinone, } \\
\text { menadione) }\end{array}$ & $\begin{array}{l}\text { Clotting factors, } \\
\text { bone proteins }\end{array}$ & Hemorrhagic disease \\
\hline
\end{tabular}


Table 2: Vitamin D

\begin{tabular}{|c|c|c|c|c|}
\hline \multirow{12}{*}{$\begin{array}{l}\text { (calciferol) } 1 \\
\text { mcg calciferol } \\
=40 \mathrm{IU}\end{array}$} & Age & Micrograms daily & Micrograms daily & Adverse effects of excess \\
\hline & \multicolumn{3}{|c|}{ Infants } & \\
\hline & \multirow{2}{*}{0 to 12 months } & \multirow{2}{*}{10 (400 IU) } & 0 to 6 months: 25 (1000 IU) & \multirow{10}{*}{$\begin{array}{l}\text { Hypercalcemia, hypercalciuria, } \\
\text { polydipsia, polyuria, confusion, } \\
\text { anorexia, vomiting, bone deminer- } \\
\text { alization }\end{array}$} \\
\hline & & & 6 to 12 months: 37.5 (1500 IU) & \\
\hline & \multicolumn{3}{|c|}{ Children and adolescents } & \\
\hline & \multirow{3}{*}{1 to 18 years } & \multirow{3}{*}{15 (600 IU) } & 1 to 3 years: $62.5(2500 \mathrm{IU})$ & \\
\hline & & & 4 to 8 years: 75 (3000 IU) & \\
\hline & & & 9 to 18 years: $100(4000 \mathrm{IU})$ & \\
\hline & \multicolumn{3}{|c|}{ Males and females (including pregnancy and lactation) } & \\
\hline & 19 to 50 years & $15(600 \mathrm{IU})$ & 100 (4000 IU) & \\
\hline & 50 to 70 years & 15 & 100 & \\
\hline & $>70$ years & 20 (800 IU) & 100 & \\
\hline
\end{tabular}

\section{References}

Abdel-Motagaly, AME, Mohamad, HM, Morsy, TA, 2017: A mini-review on skeeter syndrome or large local allergy to mosquito bites. J. Egypt. Soc. Parasitol. 47, 2:415-24.

Bashutski, JD, Eber, RM, Kinney, JC, Benavides, E, Matra, S, et al, 2011: The impact of vitamin D status on periodontal surgery. J. Dent. Res. 90:1007-12.

Bikle, DD, 2014: Vitamin D metabolism, mechanism of action, and clinical applications. Chem. Biol. 21, 3:319-29.

Bitetto, D, Fabris, C, Falleti, E, Fornasiere, E, Fumolo, E, et al, 2010: Vitamin D and the risk of acute allograft rejection following human liver transplantation. Liver Int. 30:417-44.

Boucher, BJ, 2012: The problems of Vitamin D insufficiency in older people. Aging Dis. 3, 4: 313-29.

Brok, J, Huusom, L, Cortes, D, 2011: Severe vitamin D deficiency in children born in Denmark of dark-skinned women. Ugeskr. Laeger. 173, 26:1862-3.

Clemens, TL, Adams, JS, Henderson, SL, Holick, MF, 1982: Increased skin pigment reduces the capacity of skin to synthesise vitamin D3. Lancet 1:74.

Cole, CR, Grant, FK, Tangpricha, V, et al, 2010: 25-hydroxyvitamin D status of healthy, low-income, minority children in Atlanta, Georgia. Pediatrics 125:633-9.

Coussens, A, Timms, PM, Boucher, BJ, Venton, TR, Ashcroft, AT, et al, 2009: 1alpha, 25di-hyrdroxyvitamin D3 inhibits matrix metalloproteinases induced by Mycobacterium tuberculosis infection. Immunology 127:539-48.

Das, G, Crocombe, SS, McGrath, M, et al, 2006: Hypovitaminosis D among healthy adolescent girls attending an inner city school. Arch. Dis. Child. 91:569-74.
De Sévaux, RG, Hoitsma, AJ, Corstens, FH, Wetzels, JF, 2002: Treatment with vitamin D \& calcium reduces bone loss after renal transplantation: a randomized study. J. Am. Soc. Nephrol. 13:1608-14.

El-Tawdy, AHF, Hemdan, MSA, Isa, WEA, Morsy, TA: An update view of Vitamin D and Type 2 diabetes mellitus. (In Press).

Ertek, S, Akgül, E, Cicero, AF, Kütük, U, Demirtaş, S, et al, 2012: 25 -Hydroxy vitamin D levels and endothelial vasodilator function in normotensive women. Arch. Med. Sci. 29:47-52. Fraser, D, Scriver, CR, 1979: Hereditary disorders associated with vitamin D resistance or defective phosphate metabolism. In: Endocrinology, by De-Groot, LJ, Grune and Stratton, N.Y. Gartner, LM, Morton, J, Lawrence, RA, et al, 2005: Breastfeeding and the use of human milk. Pediatrics 115:496-8.

Goldblatt, H, Soames, KM, 1923: A Study of Rats on a Normal Diet Irradiated daily by the Mercury Vapour Quartz Lamp or kept in Darkness. Biochem. J. 17:294-9.

Goltzman, D, Hendy, GN, White, JH, 2015: Vitamin D and its receptor during late development. Biochim. Biophys. Acta. 1849, 2:171-80

Gordon, CM, DePeter, KC, Feldman, HA, et $\boldsymbol{a l}$, 2004: Prevalence of vitamin D deficiency among healthy adolescents. Arch. Pediatr. Adolesc. Med.158:531-6.

Grant, WB, 2012: Ecological studies of the UVB-vitamin D-cancer hypothesis. Anticancer Res. 32:223-36.

Gröber, U, Kisters, K, 2012: Influence of drugs on vitamin $\mathrm{D}$ and calcium metabolism. Dermatoendocrinol. 4, 2:158-66.

Guerreiro, PM, Larry Renfro, J, Power, DM, Canario, AVM, 2007: The parathyroid hormone family of peptides: structure, tissue distri- 
bution, regulation, and potential functional roles in calcium and phosphate balance in fish Am. J. Physiol. Regulat, Integrat. Comparat. Physiol. 292, 2:R679-96.

Harris, RA, Pedersen-White, J, Guo, DH, Stallmann-Jorgensen, IS, Keeton, D, et al, 2011: Vitamin D3 supplementation for 16 weeks improves flow-mediated dilatation in overwieght African-American adults. Am. J. Hypertens. 24: 557-62.

Hazzazi, MA, Alzeer, I, Tamimi, W, Al Atawi, M, Al Alwan, I, 2013: Clinical presentation and etiology of osteomalacia/rickets in adolescents. Saudi J. Kidney Dis. Transpl. 24, 5:93841

Henry, HL, Norman, AW, 1974: Studies on calciferol metabolism. IX. Renal 25-hydroxyvitamin D3-1 hydroxylase: Involvement of cytochrome P-450 and other properties. J. Biol. Chem. 249:7529-32.

Holick MF, 1989: Biosynthesis, metabolism, and mode of action. In: Endocrinology, DeGroot LJ (Ed), Grune and Stratton, New York.

Holick, MF, 1994: McCollum Award Lecture, 1994: vitamin D--new horizons for the $21^{\text {st }}$ century. Am. J. Clin. Nutr. 60:619-24.

Holick, MF, 1996: Vitamin D and bone health. J. Nutr. 126: S1159-62.

Holick, MF, 2006: High prevalence of vitamin D inadequacy and implications for health. Mayo Clin. Proc. 81:353-6.

Holick MF, 2011: Photobiology of vitamin D. In: Feldman D, Pike JW, Adams JS, editors. Vitamin D. Vol. 1. Academic Press; Elsevier.

Holick, MF, Krane, SM, Potts, JT, 1995: Calcium, phosphorus, and bone metabolism: Calcium-regulation hormones. In: Harrison's principles of internal medicine, 14th, Fauci AS, Braunwald E, Isselbacher KJ, et al (Eds), McGraw-Hill, New York.

Hollis, BW, Wagner, CL, 2004a: Vitamin D requirements during lactation: high-dose maternal supplementation as therapy to prevent hypovitaminosis $\mathrm{D}$ for both the mother and the nursing infant. Am. J. Clin. Nutr. 80:S1752-62.

Hollis, BW, Wagner, CL, 2004: Assessment of dietary vitamin D requirements during pregnancy and lactation. Am. J. Clin. Nutr. 79:717-22.

IARC, 2008: Working Group Report 5: Vitamin $\mathrm{D}$ and cancer. http://www.iarc.fr/en/MediiaCentre/IARC-News?VitaminD and Cancer

IOM, 2010: Institute of Medicine. Report at a Glance, Report Brief: Dietary Reference Intakes for Calcium and Vitamin D, released file:// www.iom.edu/Reports/Dietary-Reference-Intakes-for-Calcium-and-Vitamin-D/ReportBrief.aspx Jabbar, S, Drury, J, Fordham, J, Datta, HK, Francis, RM, et al, 2011: Plasma vitamin D and cytokines in periodontal disease and postmenopausal osteoporosis. J. Periodontal. Res. 46:97104.

Kalav, UR, Cha, SS, Takahashi, P, 2011: Association between vitamin D and pressure ulcers in older ambulatory adults: results of a matched case-control study. Clin. Interv. Ageing 6:213-9. Keating, P, Munim, A, Hartmann, JX. 2014: Effect of vitamin D on T-helper type 9 polarized human memory cells in chronic persistent asthma. Ann. Allergy Asthma Immunol. 112, 2:15462.

Keshtkar, AA, Ebrahimi, M, Khashayar, P, Abdollahi, Z, Pouraram, H, et al, 2015: Community Interventional Trial (CITFOMIST) of Vitamin D fortified versus non-fortified milk on serum levels of $25(\mathrm{OH}) \mathrm{D}$ in the students of Tehran. Arch. Iran Med. 18, 5:272-6.

Keshtkar, AA, Khashayar, P, Mohammadi, Z, Etemad, K, Dini, M, et al, 2015b: A suggested prototype for assessing bone health. Arch. Iran Med. 18, 7:411-5.

Kim, G, Bae, JH, 2016: Vitamin D and atopic dermatitis: A systematic review and meta-analysis. Nutrition 32, 9:913-20.

Kovacs, CS, Kronenberg, HM, 1997: Maternal-fetal calcium and bone metabolism during pregnancy, puerperium, and lactation. Endocr. Rev.18:832-8.

Lee, V, Rekhi, E, Kam, JH, Jeffrey, G, 2012: Vitamin $D$ rejuvenates ageing eyes by reducing inflammation, clearing amyloid beta and improving visual function. Neurobiol Ageing. 2012 Jan 2; [ahead of print]

Lips, P, Hosking, D, Lippuner, K, et al, 2006: The prevalence of vitamin D inadequacy amongst women with osteoporosis: an international epidemiological investigation. J. Intern. Med. 260:245-52.

MacLaughlin, J, Holick, MF, 1985: Aging decreases the capacity of human skin to produce vitamin D3. J. Clin. Invest. 76:1536-40.

Mansbach, JM, Ginde, AA, Camargo, CA Jr, 2009: Serum 25-hydroxyvitamin D levels among US children aged 1 to 11 years: do children need more vitamin D? Pediatrics 124:1404-10.

Martineau, AR, Timms, PM, Bothamley, GH, Hanifa, Y, Islam, K, et al, 2011: High-dose 
vitamin $\mathrm{D}(3)$ during intensive-phase antimicrobial treatment of pulmonary tuberculosis: a double-blind randomized controlled trial. Lancet 377:242-50.

Mellanby, E, 1918: The part played by an accessory factor in the production of experimental rickets. Lancet, December 7.

Misra M, Pacaud D, Petryk A, et al, 2008: Vitamin D deficiency in children and its management: review of current knowledge and recommendations. Pediatrics 122:398-402.

Morgan, SL, Weinsier, RL, 1998: Fundamentals of clinical nutrition, Mosby, St. Louis.

Morsy, TA, 2012: Insect bites and what is eating you? J. Egypt. Soc. Parasitol. 42, 2:291-308. Muirhead, N, Adami, S, Sandler, LM, Fraser, RA, Catto, GR, et al, 1982: Long-term effects of 1,25-dihydroxy vitamin D3 and 24,25dihydroxy vitamin D3 in renal osteodystrophy. Q. J. Med. 51, 204:427-44.

Munns, CF, Shaw, N, Kiely, M, Specker, BL, Thacher, TD, et al, 2016: Global consensus recommendations on prevention and management of nutritional rickets. J. Clin. Endocrinol. Metab. 101, 2:394-415.

Timms, PM, Mannan, N, Hitman, GA, Noonan, K, Mills, PG, et al, 2014: The circulating MMP9, vitamin D and variation in the TIMP-1 response with VDR genotype: mechanisms for inflammatory damage in chronic disorders? Q. J. M. 95:787-96.

Ross, AC, Manson, JE, Abrams, SA, et al, 2011: The 2011 report on dietary reference intakes for calcium and vitamin D from the Institute of Medicine: what clinicians need to know? J. Clin. Endocrinol. Metab. 96:53-60.

Sahota, O, 2014: Understanding vitamin D deficiency. Age Ageing. 43, 5:589-91.

Seals, DR, Jablonski, KL, Donato, AJ, 2011: Ageing and vascular endothelial function in humans. Clin. Sci. (Lond.) 120:357-75.

Sunyecz, JA, 2008: The use of calcium and vitamin D in the management of the osteoporosis. Ther. Clin. Risk Manag. 4, 4: 827-36.

Terenetskaya, I, 2004: Two methods for direct assessment of the Vitamin D synthetic capacity of sunlight and artificial UV sources. J. Steroid Biochem. Mol. Biol. 89-90, 1/5:623-6.

Tian, XQ, Chen, TC, Holick, MF, 1995: 1,25dihydroxyvitamin D3: a novel agent for enhancing wound healing. J. Cell Biochem. 59:53-6.

Timms, PM, Mannan, N, Hitman, GA, Noonan, K, Mills, PG, et al, 2002: The circulating
MMP9, vitamin D and variation in the TIMP-1 of rickets. J. Physiol. 52:11-6.

Tillis, CC, Huang, HW, Bi, W, Pan, S, Bruce, SR, et al, 2011: Glucocorticoid regulation of human pulmonary surfactant protein-B (SP-B) mRNA stability is independent of activated glucocorticoid receptor. Am. J. Physiol. Lung Cell Mol. Physiol. 300, L940-50.

Topannen, AM, Williams, D, Hendersen, J, Lawlor, DA, 2011: Serum 25-hydroxyvitamin D and ionised calcium in relation to lung function and allergen skin tests. Eur. J. Clin. Nutr. 65: 493-500.

Tsai, KS, Wahner HW, Offord KP, et al, 1987: Effect of aging on vitamin $D$ stores and bone density in women. Calcif. Tissue Int. 40: 241-9.

Tsujimoto, Y, Tahara, H, Shoji, T, Emoto, M, Koyama, H, et al, 2011: Active vitamin D and acute respiratory infections in dialysis patients. Clin. J. Am. Soc. Nephrol. 6:1361-7.

Tsujimoto, Y, Tahara, H, Shoji, T, Emoto, M, Koyama, H, et al, 2011: Active vitamin D and acute respiratory infections in dialysis patients. Clin. J. Am. Soc. Nephrol. 6:1361-7.

Vieth, R, 1999: Vitamin D supplementation; 25 hydroxyvitamin D concentrations, and safety. Am. J. Clin. Nutr. 69:842-56.

Wagner, CL, Frank R. Greer, FR, et al, 2008: Prevention of rickets and Vitamin D deficiency in infants, children, and adolescents. Pediatrics 122, 5:1142-52.

Webb, AR, Kline, L, Holick, MF, 1988: Influence of season and latitude on the cutaneous synthesis of vitamin D3: Exposure to winter sunlight in Boston and Edmonton will not promote vitamin D3 synthesis in human skin. J. Clin. Endocrinol. Metab. 67:373-6.

WHO, 2002: file://whqlibdoc.who.int/ publications/9241562110.pdf. Geneva,

Windaus, A, Schenck, F, Von Werder, F, 1936: About the antirachitic irradiation product of 7-dehydrocholesterol. Hoppe Seylers Z. Physiol. Chem. 241:100-10

Wouters, E, Wojciechowski, M, de Vries, E, 2015: Two cases of rickets presenting with poor growth, hypotonia, and respiratory problems. Acta Clin. Belg. 70, 3:211-4.

Zhou, J, Chew, M, Ravn, HB, Falk, E, 1999: Plaque pathology and coronary thrombosis in the pathogenesis of acute coronary syndromes. Scand. J. Clin. Lab. Invest. 230, 1:S3-11. 